\title{
Isolation, Purification of Quercetin from in vitro Cell Suspension Culture of Caesalpinia pulcherrima and its Analysis by HPLC-DAD and NMR
}

\author{
Aswathy Jayasree Madanakumar, Greeshma Murukan, Bosco Lawarence, Murugan Kumaraswamy*
}

\section{Aswathy Jayasree Madan- akumar, Greeshma Muru- kan, Bosco Lawarence, Murugan Kumaraswamy*}

Plant Biochemistry and Molecular Biology Laboratory, University College, Trivandrum, Kerala, INDIA.

Correspondence

\section{Dr K Murugan}

Plant Biochemistry and Molecular Biology Laboratory, University College, Trivandrum, Kerala, INDIA.

Phone no: 0-0471-2110155

E-mail: harimurukan@gmail.com

History

- Submission Date: 14-07-2017;

- Review completed: 04-08-2017;

- Accepted Date: 02-11-2017

DOI : 10.5530/pj.2017.6s.156

Article Available online

http://www.phcogj.com/v9/i6s

\section{Copyright}

(C) 2017 Phcog.Net. This is an openaccess article distributed under the terms of the Creative Commons Attribution 4.0 International license.

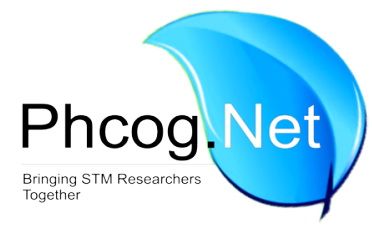

\begin{abstract}
Background: Caesalpinia pulcherrima, belongs to Caesapiniaceae, is a known medicinal plant widely distributed in India and is used in traditional medicine for the treatment of various ailments. Many phytochemicals are reported from the plant as potential source of crude drug. Materials and Methods: An efficient and simple reproducible protocol was developed for callus production using leaf explants of $C$. pulcherrima. The combination of 2, 4-D, kin and BA, was used for the callus induction. Subsequently, cell suspension culture and quercetin synthesis from in vitro callus was attempted. Role of effect of elicitors (Sucrose, ABA and salicylic acid) in cell suspension culture was carried in MS medium containing 2,4-D + BA + kinetin. Flavonoids was purified, fractionated by HPLC-DAD and NMR. Results: 2, 4-D (2.5 $\mathrm{mg} / \mathrm{L})$, BA $(2.5 \mathrm{mg} / \mathrm{L})+\mathrm{kin}(1 \mathrm{mg} / \mathrm{mL})$ was effective for maximum callus induction from leaf explants. Significant cell suspension culture was noticed with liquid MS medium containing 2,4-D (2 mg/L)+ BA (1 mg/L)+ kinetin (1.5 mg/L). Sucrose, ABA and salicylic acid (SA) at different concentrations influenced cell biomass and quercetin accumulation. The addition of ABA/SA along with sucrose was found to have no remarkable effect on cell biomass and also quercetin synthesis. However, cells cultured in the medium fortified with $45 \mathrm{~g} / \mathrm{L}$ sucrose without ABA/ SA showed the highest quercetin content $(16.5 \mathrm{mg} / \mathrm{g})$. Flavonoids was purified, fractionated by HPLC-DAD and NMR revealed the presence of 9 components such as quercetin, isoquercetin, quercetrin, rutin, quercetin 3-O- $\beta$-D-xyloside, quercetin 3-Oarabinopyranoside, quercetin 3-O$\alpha$-arabinopyranosyl $(1 \rightarrow 2) \beta$-galactopyranoside, isorhamnetin 3-O-rutinoside and an unknown compound. Conclusion: $C$. pulcherima reveals significant synthesis of quercetin. Quercetin content recorded in cell suspension culture was significantly higher compared with in vivo plants grown in fields and the compounds were identified by NMR.
\end{abstract}

Key words: Caesalpinia pulcherrima, Callus, Cell suspension culture, Elicitors; growth hormones, Quercetin.

\section{INTRODUCTION}

Flavonoids are polyphenolic pigments induce flower coloration, but also possess taste and toxicity. They function as messenger cascades and contribute defense against herbivory and pathogens. Flavonoids possess a general structure of $15 \mathrm{C}$ atoms, with 2 phenyl rings and a heterocyclic ring, that are connected by carbon bridge. ${ }^{1}$ The substituents in the heterocyclic ring $\mathrm{C}$, and the varying forms of the ring are the lead characters used for their classification. Six subclasses are recognized among flavonoids such as flavones, flavonols, isoflavones, flavanones, anthocyanidins, and flavan-3-ols, which are commonly known as catechins. Multiple substituents can be present in the structural skeleton, with hydroxyl groups normally in $4^{\prime}, 5^{\prime}$ and 7 ' positions.

Flavonols are universal group of the flavonoids and are reported in all plants except algae and fungi. Most flavonols can be found as O-glycosides and the common among then are quercetin, myricetin, and kaempferol.
The biosynthesis of polyphenolic compounds is via shikimate phenylpropanoid pathways.

Caesalpinia pulcherrima Swartz. belonging to Caesalpiniaceae possess wide folklore medicinal uses. Leaves, flower, bark, and seeds are used in Indian medicine and distributed widely in India. The plant has been considered as a tonic and stimulant. The bark and leaf infusions are used as an abortifacient and cathartic. The plant is rich in active ingredients like caesalpin-type diterpenoids, sitosterol, pulcherrimin, lupeol, lupeol acetate, myricetin, quercetin, rutin, flavonoids, carotenoids, glycosides, peltogynoids, phenols, and steroids. ${ }^{2}$

In recent decades, there are many well established herbal and plant based medicinal practices like Ayurvedic medicine which are popular in many parts of the world. The World Health Organization reported that $80 \%$ of people in the devel-

Cite this article: Aswathy JM, Murukan G, Lawarence B, Murugan K. Isolation, Purification of Quercetin from in vitro Cell Suspension Culture of Caesalpinia pulcherrima and its Analysis by HPLC -DAD and NMR. Pharmacog J. 2017;9(6)Suppl:s44-s51. 
oping countries use herbals for their primary health needs. $^{3}$ About $40 \%$ of compounds used in pharmaceutical industry are directly or indirectly derived from plants because the chemical synthesis of such compounds is either not feasible and/or economically unviable. Therefore, a large number medicinal species are under threat of extinction because of their over exploitation. Tissue culture offers an effective and potential alternative of secondary metabolite production because the amount of secondary metabolites produced in in vitro cultures can be even higher than in parental plants. ${ }^{4}$ Advances in plant tissue culture have enabled commercial scale production of plant metabolites. Many problems need to be tackled in tissue culture to increase the production of secondary metabolites in plant species. One of the major issues is heterogeneity of plant cells and difference in morphological characteristics of each individual cell from the others, this has a huge effect. Different types of cell cultures (suspension and hairy root) are used to transform the natural molecules like steroid, alkaloid, coumarin, terpenoid, lignan and many others flavouring compounds through biotransformation. ${ }^{5}$ In this juncture present study is undertaken to analyze flavonoids in Caesalpinia pulcherrima, via cell suspension culture, elicitation of flavonoids, its purification, fractionation and its analyses by HPLC-DAD and NMR.

\section{MATERIAL AND METHODS}

\section{Plant material}

The fresh excised Caesalpinia pulcherrima (L.) Sw. shoot tips and young leaves were collected from their wild habitats.

\section{Sterilization of explants}

Explants were washed under running tap water for 20 min to make them free from dirt and foreign particles followed by dipping in $2 \%$ tween 20 for 10 to $15 \mathrm{~min}$ and then dipped in $1 \%$ Bavistin for $30 \mathrm{~min}$, rinsed thrice with deionized distilled water. It was further surface sterilized using $70 \%$ ethanol for 3-5 min followed by $0.1 \% \mathrm{HgCl}_{2}$ for a min and then again washed with deionized distilled water thrice to remove the traces of $\mathrm{HgCl}_{2}$.

\section{In vitro culture}

Sterilized explants were cultured on full, half strength MS medium fortified with 2, 4- dichloro phenoxy acetic acid (2,4-D) 0.5-5 mg/L, BA 1-5 mg/L, kinetin $0.5-2.5 \mathrm{mg} / \mathrm{L}$ and also in combination of these. Culturing conditions are maintained under $16 / 8 \mathrm{~h}$ photoperiod at $25 \pm 2^{\circ} \mathrm{C}$ for callus induction.

\section{Cell suspension culture}

The cell suspension culture of C. pulcherrima was prepared by inoculating $0.5 \mathrm{~g}$ (fresh weight) of $9^{\text {th }}$ day old cells into liquid MS basal medium containing varying concentrations of $0.5-2 \mathrm{mg} / \mathrm{L} \mathrm{BA}, 0.5-2 \mathrm{mg} / \mathrm{L} 2,4-\mathrm{D}$ and kin $0.5-2.5 \mathrm{mg} / \mathrm{L}$ as the cell proliferation medium. ${ }^{6,7}$ Sterile stainless steel sieve with $850 \mu \mathrm{m}$ pore size was used to filter the initial established cell cultures to obtain homogenous cell suspension culture. Homogenous cells or small cell aggregates that has been passed through the sieve (with diameter $<850 \mu \mathrm{m}$ ) were subsequently filtered through What man No. 1 filter paper using an air suction pump to separate the cells from the medium.

The cell cultures were placed on an shaker at 100-120 rpm in a culture room maintained at $24 \pm 2^{\circ} \mathrm{C}$ under continuous illumination with cool white fluorescent tubes at a light intensity of 6.3-11.9 $\mu \mathrm{mol}$ photons $\mathrm{m}^{-2} \mathrm{sec}^{-1}$. Regularly, the cells were harvested and used as samples for subsequent studies.

\section{Effect of sucrose}

$0.5 \mathrm{~g}$ cell biomass obtained from the cell suspension culture which was sub-cultured every $9^{\text {th }}$ day in liquid MS medium fortified with $2.5 \mathrm{mg} / \mathrm{L}$ $\mathrm{BA}+1 \mathrm{mg} / \mathrm{L} 2,4-\mathrm{D}+1 \mathrm{mg} / \mathrm{L} \mathrm{kin}$ and exposed to continuous illumination was inoculated into each of the $100 \mathrm{ml}$ Erlenmeyer flasks containing $20 \mathrm{ml}$ liquid MS medium fortified with different concentrations of sucrose $(0,15,30,45,60,75$ and $90 \mathrm{~g} / \mathrm{L})$. Six replicates were used for each sucrose concentration treatment.

\section{Elicitation}

Elicitors were employed to the suspension cells to induce the synthesis of quercetin glycosides. Physical elicitors used in this study include light (24 h), dark ( $24 \mathrm{~h}$ ) and UV light treatment ( $45 \mathrm{~min} /$ day). Chemical elicitors like gibberellin (0.05- $1.5 \mathrm{mg} / \mathrm{L})$, abscisic acid $(0.05-1.5 \mathrm{mg} / \mathrm{L})$ and heavy metals like $\mathrm{CuSO}_{4}$, and $\mathrm{ZnSO}_{4}(25-100 \mu \mathrm{M})$. Organic elicitors such as coconut water (10-50\%), yeast extract (0.1-0.5\%), phenylalanine (100 $500 \mu \mathrm{M})$ and peptone water $(0.001-0.1 \%)$. Salicylic acid $(1-100 \mu \mathrm{M})$ and MeJA 100- $1000 \mu \mathrm{M}$ was also trailed. Cultures without elicitor were included as control group. Sampling was performed $6^{\text {th }}$ day after addition of the elicitors up to $24^{\text {th }}$ day of culture.

Cell aggregates and the liquid medium were separated as per the standard protocol. The fresh cell mass was determined after the cells were harvested. The quercetin content was determined from the harvested cells as stated below.

\section{Effect of sucrose and elicitors combinations}

$0.5 \mathrm{~g}$ cell mass was inoculated into two diverse culture media: (a) liquid MS medium fortified with $1 \mathrm{mg} / \mathrm{L} \mathrm{BA}+2 \mathrm{mg} / \mathrm{L} 2,4-\mathrm{D}+1.5 \mathrm{mg} / \mathrm{L} \mathrm{kin} \mathrm{+}$ $30 \mathrm{~g} / \mathrm{L}$ sucrose (the normal sucrose content used in MS medium) and (b) liquid MS medium fortified with $1 \mathrm{mg} / \mathrm{L} \mathrm{BA}+2 \mathrm{mg} / \mathrm{L}$ 2,4-D + $1.5 \mathrm{mg} / \mathrm{L}$ kin $+45 \mathrm{~g} / \mathrm{L}$ sucrose (optimal sucrose concentration that induced the highest quercetin synthesis). SA concentration of $50 \mu \mathrm{M} / 0.1 \mathrm{mg} / \mathrm{L}$ ABA was added into the medium at day zero, $3^{\text {rd }}$ day and $6^{\text {th }}$ day of culture. The addition of elicitors at the beginning of cell culture ( 0 day) was used as control. The cultures were maintained under continuous light with intensity of 6.3-11.9 $\mu \mathrm{mol}$ photons $\mathrm{m}^{-2} \mathrm{sec}^{-1}$ and the cells were harvested at the end of $9^{\text {th }}$ day of culture. The cell mass and quercetin content and synthesis were then determined.

\section{Quantification of flavonoids}

Total flavonoids were determined by the standard protocol. ${ }^{8}$

\section{Extraction, fractionation, and purification of quercetin derivatives}

Cell suspension cultures were extracted with methanol at room temperature for $48 \mathrm{~h}$ and was filtered and concentrated under reduced pressure to yield a crude extract and was diluted in methanol water to a ratio of 9:1, and then extracted successively with $n$-hexane, dichloromethane, ethyl acetate and $n$-butanol.

Ethyl acetate and $n$-butanol fractions were separately chromatographed on amberlite XAD-16 columns $(2 \mathrm{~m} \times 8 \mathrm{~cm})$. Aqueous methanol solutions (from $0 \%$ to $100 \%$, with $10 \%$ increments) were used as the mobile phase, and 11 fractions were collected for each extract (fractions EA1EA11 and B1-B11, for Ethyl acetate and $n$-butanol, respectively). The fractions were pooled and subjected to Sephadex LH-20 chromatography $(30 \mathrm{~cm} \times 45 \mathrm{~mm})$ with methanol water $(1: 1)$ as the mobile phase.

\section{Reverse-phase HPLC-DAD analyses}

HPLC-DAD (High Performance Liquid Chromatography with Diode Array Detector) was used to analyze the chemical composition of ethyl aceate and $n$-butanol fractions described above. The mobile phase of HPLC-DAD analysis consisted of (A) $1 \%$ phosphoric acid in water or (B) $1 \%$ phosphoric acid in methanol. Gradients used were: 0-15 min $50-70 \%$ of B followed by $15-25 \min 70-100 \%$ of $\mathrm{B}$. The flow rate was 
$1 \mathrm{~mL} / \mathrm{min}$ and the injection volume $20 \mu \mathrm{L}$. The UV-vis spectra were recorded from 254 to $400 \mathrm{~nm}$, with detection at 254 and $365 \mathrm{~nm}$.

\section{Nuclear magnetic resonance (NMR) analysis}

${ }^{13} \mathrm{C}-\mathrm{NMR}$ spectra were run on a Bruker AV NMR instrument equipped with $5 \mathrm{~mm}{ }^{13} \mathrm{C}$ operating at $500 \mathrm{MHZ}$ with tetra methyl silane (TMS) as an internal standard.

\section{Statistical analysis}

Experiment was repeated three times and triplicates were maintained each treatments. All data are represented as mean \pm SD. Data were analyzed by one way analysis of variance (ANOVA) at $5 \%$ probability level using SPSS software (version 16).

\section{RESULTS AND DISCUSSION}

Total flavonoid content in the flower and leaf extract of C. pulcherrima was 1.9 and $4.2 \mathrm{mg} / \mathrm{g}$ tissue respectively. Subsequently, the flavonoids were fractionated by HPLC-DAD. The analysis revealed a pool of fractions displaying varying proportions of compounds having UV absorption typical of flavonoids.

In vitro callus initiation was carried out with stem tip and leaf explants of C. pulcherrima. Maximum callus induction (39-96\%) and highest callus proliferation $(348 \pm .48-1476 \pm 0.10 \mathrm{mg} \mathrm{FW})$ was observed in half strength MS medium fortified with 2,4-D (2.5 mg/L) + $2.5 \mathrm{mg} / \mathrm{L} \mathrm{BA}$ and kin $(1.5 \mathrm{mg} / \mathrm{L})$ with $30 \mathrm{~g} / \mathrm{L}$ sucrose for all the leaf explants compared to shoot tip (Figure 1a,b and c) (Table1).

Sheeba et al. ${ }^{9}$ Studied about the callus induction caused by the effect of phytohormones on in Physalis minima and the best result in terms of $\%$ of callus induction (80.67) obtained on NAA ( $3 \mathrm{mg} / \mathrm{L}$ ) using leaf as explants after 20 days of inoculation. Ashtari et al. ${ }^{10}$ reported efficient callus induction and plant regeneration in Ducrosia anethifolia in stem tips on MS medium ( $2 \mathrm{mg} / \mathrm{L}$ NAA and $1 \mathrm{mg} / \mathrm{L} \mathrm{BA}$ ) and on MS medium containing ( $3 \mathrm{mg} / \mathrm{L}$ NAA and $1 \mathrm{mg} / \mathrm{L} \mathrm{BA}$ ) with stem, leaf and node. In Lilium leucanthum, the highest frequency of plant regeneration (96.7\%) and the highest mean number of bulblets per scale (3.07) were obtained on MS medium fortified with $0.5 \mathrm{mg} / \mathrm{L} \mathrm{BA}$ and $0.1 \mathrm{mg} / \mathrm{L}$ NAA. ${ }^{11}$ Amali et al. ${ }^{12}$ trailed MS medium supplemented with $2.0 \mathrm{mg} / \mathrm{L}$ of $2,4-\mathrm{D}$ and $0.5 \mathrm{mg} / \mathrm{L}$ of kinetin developed embryogenic calli when supplemented with $1.0 \mathrm{mg} / \mathrm{L}$ of thidiazuron (TDZ). Lood et al. ${ }^{13}$ initiated calli in Lagenaria siceraria with optimum concentration of hormones i.e., $2.0 \mathrm{mg} / \mathrm{L} 3.3 \mathrm{BA}+1.0 \mathrm{mg} / \mathrm{L}$ NAA.

Bonyanpour and Khosh-Khui ${ }^{14}$ induced calli in Punica granatum L. 'Nana' from leaf explants with $1 \mathrm{mg} / \mathrm{L}$ BA and $1 \mathrm{mg} / \mathrm{L}$ NAA. Hasan et al. ${ }^{15}$ induced calli and plant regeneration from shoot tips of Cassia obtusifolia. The highest percentage of callus induction was (96.6\%) observed in the medium supplemented with $2.0 \mathrm{mg} / \mathrm{L} 2,4-\mathrm{D}$. The highest number of shoots was 5.0 found in the medium having $2.0 \mathrm{mg} / \mathrm{L}$ 2.4-D+0.2 mg/L Kin.

Hasan et al. ${ }^{16}$ developed in vitro callus induction and regeneration from nodal explants of Cassia alata. Greenish friable callus was obtained from the excised nodal explants on MS medium supplemented with $1.5 \mathrm{mg} / \mathrm{L}$ 2,4-D within 20 days of inoculation. Tan et al. ${ }^{17}$ studied the effect of plant growth regulators on callus, cell suspension and cell line selection for flavonoid synthesis from Centella. The highest percentage of callus induction (86.67\%) was observed in MS medium fortified with $2.0 \mathrm{mg} / \mathrm{L}$ 2,4-D while highest biomass yield $\left(0.27 \mathrm{~g}\right.$ dry weight culture $\left.{ }^{-1}\right)$ was obtained in the combination of $2.0 \mathrm{mg} / \mathrm{L} 2,4-\mathrm{D}$ and $1 \mathrm{mg} / \mathrm{L}$ kinetin in MS medium.

Aghaei et al. ${ }^{18}$ compared different plant growth hormones on callus induction of stem explants in Pistacia atlantica subsp. Kurdica. The high efficient callus formation was observed in the medium containing
Table 1: Effect of different combinations of phytohormones on callus induction (\%) and callus fresh weight $(\mathrm{mg})$ and callus morphology of $C$. pulcherima

\begin{tabular}{|c|c|c|c|}
\hline $\begin{array}{c}\text { Hormonal } \\
\text { combinations }\end{array}$ & $\begin{array}{c}\% \text { callus } \\
\text { induction }\end{array}$ & $\begin{array}{c}\text { Callus } \\
\text { proliferation } \\
\text { mg FW }\end{array}$ & Nature of callus \\
\hline \multicolumn{4}{|l|}{ 2,4-D } \\
\hline 0.5 & 42 & $443 \pm 0.8$ & Cream friable \\
\hline 1 & 49 & $487 \pm 0.84$ & Cream friable \\
\hline 2 & 65 & $669 \pm 1.3$ & Green friable \\
\hline 3 & 54 & $534 \pm 0.77$ & Cream friable \\
\hline 4 & 40 & $400 \pm 0.60$ & Cream friable \\
\hline 5 & 39 & $348 \pm .48$ & Cream friable \\
\hline \multicolumn{4}{|l|}{ BA } \\
\hline 1 & 39 & $351 \pm 0.60$ & Cream friable \\
\hline 2 & 58 & $587 \pm 0.52$ & Cream friable \\
\hline 3 & 50 & $502 \pm 0.4$ & Cream friable \\
\hline 4 & 44 & $447 \pm 0.24$ & Cream friable \\
\hline 5 & 42 & $440 \pm 0.21$ & Cream friable \\
\hline \multicolumn{4}{|l|}{ Kin } \\
\hline 0.5 & 60 & $601 \pm 0.73$ & Cream friable \\
\hline 1 & 64 & $639 \pm 0.8$ & Green friable \\
\hline 1.5 & 69 & $702 \pm 0.9$ & Green friable \\
\hline 2 & 43 & $448 \pm 0.6$ & Cream friable \\
\hline 2.5 & 40 & $400 \pm 0.4$ & \\
\hline \multicolumn{4}{|l|}{$2,4-\mathrm{D}+\mathrm{BA}$} \\
\hline $1+1$ & 55 & $547 \pm 0.46$ & Green friable \\
\hline $2+2$ & 63 & $632 \pm 0.5$ & Green friable \\
\hline $2.5+2.5$ & 68 & $677 \pm 0.58$ & Green friable \\
\hline $3+3$ & 50 & $490 \pm 0.3$ & Cream friable \\
\hline 2,4-D+ Kin & & & Cream friable \\
\hline $1+0.5$ & 58 & $590 \pm 0.49$ & Cream friable \\
\hline $2+1$ & 66 & $678 \pm 0.56$ & $\begin{array}{l}\text { Whitish Cream } \\
\text { friable }\end{array}$ \\
\hline $2.5+1.5$ & 70 & $786 \pm 0.6$ & Cream friable \\
\hline $3+2$ & 59 & $589 \pm 0.5$ & Cream friable \\
\hline \multicolumn{4}{|l|}{$2,4-\mathrm{D}+\mathrm{Kin}+\mathrm{BA}$} \\
\hline $1+0.5+1$ & 76 & $1112 \pm 0.8$ & Green friable \\
\hline $2+1+2$ & 89.6 & $1234 \pm 0.9$ & Green friable \\
\hline $2.5+1.5+2.5$ & 96.3 & $1476 \pm 0.10$ & Green friable \\
\hline $3+2+3$ & 71 & $1095 \pm 0.98 \pm$ & Green friable \\
\hline
\end{tabular}

different concentration of 6-BA individually. The lowest and highest percentage of callus induction were in the treatment of BA $2 \mathrm{mg} / \mathrm{L}$ with NAA $1 \mathrm{mg} / \mathrm{L}(40 \%)$ and 6BA $1 \mathrm{mg} / \mathrm{L}$ (85\%), respectively. Song-Chol Mu and Gwan-Sim Mun ${ }^{19}$ developed an efficient callus proliferation system for Rheum coreanum. The callus was successfully induced from rhizome explant on MS medium containing 2.4-D (0.2-0.3 mg/L). In the MS medium supplemented with a combination of BA $(2 \mathrm{mg} / \mathrm{L})$ and NAA $(0.2 \mathrm{mg} / \mathrm{L})$, single NAA $(0.5 \mathrm{mg} / \mathrm{L})$, or IBA $(0.5 \mathrm{mg} / \mathrm{L})$, a higher number of shoot, root and plantlets was achieved. All these reports confirm that the callus initiation varies among plants with respect to hormonal 

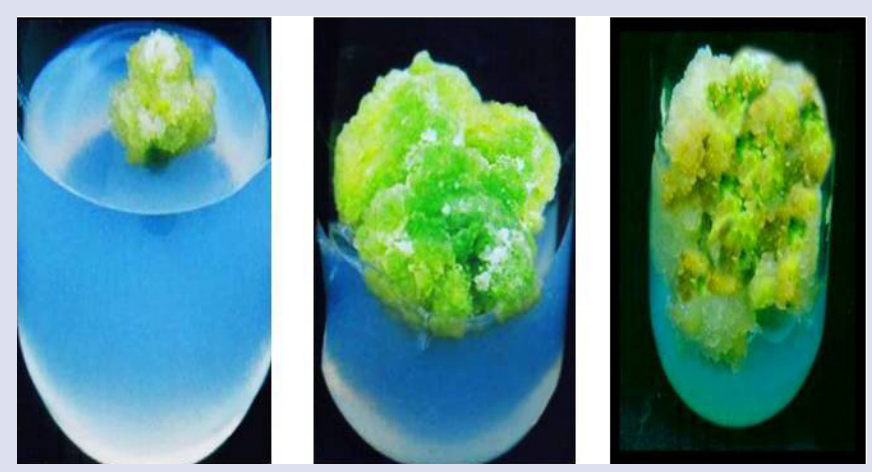

Figure $1 \mathbf{a}, \mathbf{b}, \mathbf{c}$ : In vitro callus induction from leaf explants of C.pulcherima showing green creamy friable type.
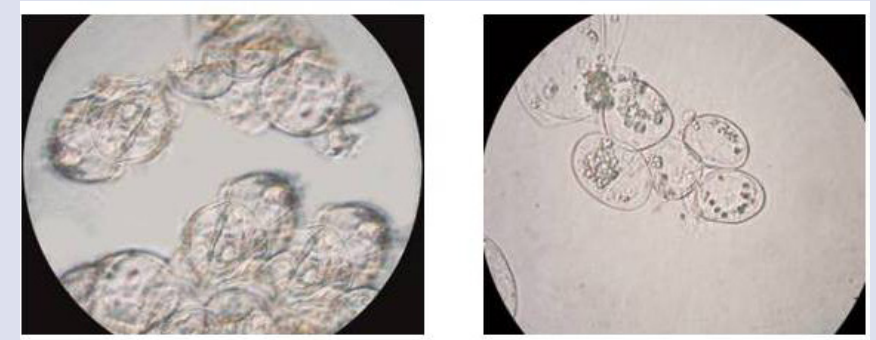

Figure 2: Viable cells from suspension culture of C.pulcherima

Table 2: Effect of different combinations of 2, 4-D + BA + kin on cellular biomass (g FW) of C. pulcherima

\begin{tabular}{cc}
\hline Hormonal combinations & Cell biomass ( $\mathrm{g}$ FW) \\
\hline $2,4-\mathrm{D}+\mathrm{BA}+$ kin & \\
$0.5+0.5+0.5$ & $3.7 \pm 0.08$ \\
$0.5+1+0.5$ & $4 \pm 0.10$ \\
$1+0.5+1$ & $4.6 \pm 0.13$ \\
$1+1+1$ & $6 \pm 0.2$ \\
$1.5+1.5+1.5$ & $5.8 \pm 0.3$ \\
$1.5+1+1.5$ & $6.9 \pm 0.36$ \\
$2+1+1.5$ & $7.66 \pm 0.45$ \\
$2+1.5+2$ & $6.2 \pm 0.48$ \\
$2+1.5+2.5$ & $5.7 \pm 0.38$ \\
\hline
\end{tabular}

combinations and explants. Subsequently, the fresh harvested callus was proceeded to initiate cell suspension cultures.

Based on the growth index, the cell culture of C. pulcherrima could be well maintained with an initial inoculum of $0.5 \mathrm{~g}$ of fresh cells inoculated into $20 \mathrm{~mL}$ of liquid MS medium contain $2 \mathrm{mg} / \mathrm{L} \mathrm{2,} \mathrm{4-D} \mathrm{+} 1 \mathrm{mg} / \mathrm{L} \mathrm{BA}+$ $1.5 \mathrm{mg} / \mathrm{L}$ kin in $100 \mathrm{~mL}$ Erlenmeyer flasks and placed on a rotary shaker at $100-120 \mathrm{rpm}$. Remarkable cell suspension culture was recorded with these combinations (Figure 2 and table 2). Generally, plant cell suspension cultures fail to detach completely after division, and forms multi-cellular aggregates..$^{20}$ During subculture, a sterilized stainless steel sieve with $850 \mu \mathrm{m}$ pore size was employed to separate small cell clumps from the larger clumps. Smaller clumps were selected for the quercetin analysis

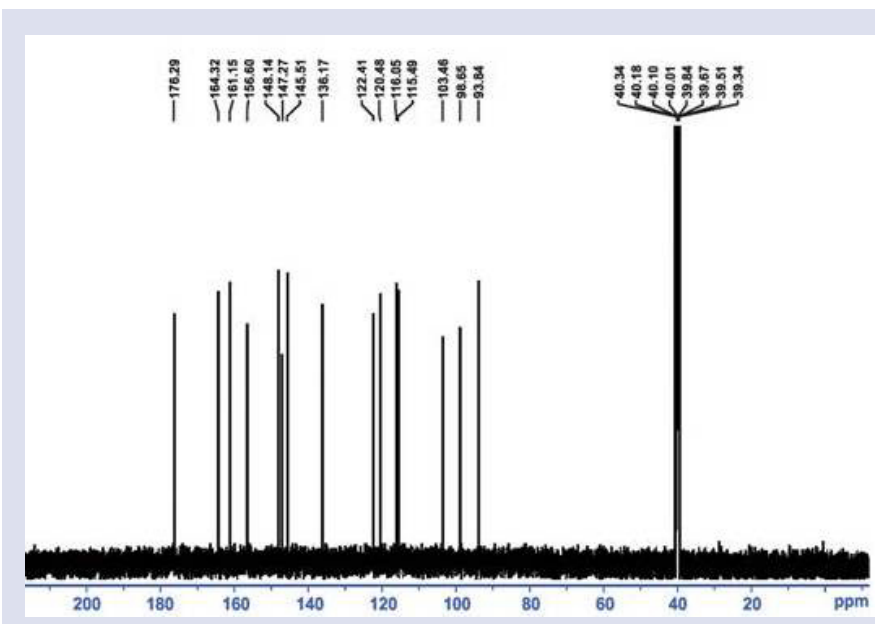

Figure 3: CNMR profile of quercetin and its derivatives of C.pulcherima

Table 3: Effect of different combinations of 2, 4-D + BA + kin on quercetin content $(\mathrm{mg} / \mathrm{g})$ of C. pulcherima

\begin{tabular}{cc}
\hline Hormonal combinations & $\begin{array}{c}\text { Quercetin content } \\
(\mathrm{mg} / \mathrm{g})\end{array}$ \\
\hline $2,4-\mathrm{D}+\mathrm{BA}+\mathrm{kin}$ & $1.24 \pm 0.04$ \\
$1+1+1$ & $3.1 \pm 0.08$ \\
$1.5+1.5+1.5$ & $5.65 \pm 0.13$ \\
$1.5+1+1.5$ & $6.98 \pm 0.3$ \\
$2+1+1.5$ & $3.9 \pm 0.39$ \\
$2+1.5+2$ & $1.5 \pm 0.06$ \\
$2+1.5+2.5$ & \\
\hline
\end{tabular}

because as cell aggregates enlarge, cells seated in the interior of a large cell clumps are not properly exposed to nutrients, light, oxygen, and other micro-environmental factors compared to younger peripheral cells. This physico-chemical gradient in turn alters the cell proliferation and phytochemical production in the culture system.

The cells cultured in MS medium fortified with $1 \mathrm{mg} / \mathrm{L}$ BA along with $1 \mathrm{mg} / \mathrm{L} 2,4-\mathrm{D}$ and $1 \mathrm{mg} / \mathrm{L}$ Kin exhibited the lowest quercetin content (1.24 $\pm 0.04 \mathrm{mg} / \mathrm{g})$, whereas cells cultured in half MS medium fortified with $2 \mathrm{mg} / \mathrm{L} 2,4-\mathrm{D}+1 \mathrm{mg} / \mathrm{L} \mathrm{BA}+1.5 \mathrm{mg} / \mathrm{L}$ kin produced the maximum quercetin content of $6.98 \mathrm{mg} / \mathrm{g} \mathrm{DW}$ on $24^{\text {th }}$ day (Table 3 ). The content of quercetin increased with the growth phase of the suspension culture. Positive correlation was noticed with biomass and quercetin content in the cell cultures.

\section{Effect of Sucrose}

Different sucrose concentration influenced the cell biomass and quercetin synthesis in cell suspension cultures of C. pulcherrima. However, cultures without sucrose (control) showed cell death. Medium fortified with $15 \mathrm{~g} / \mathrm{L}$ sucrose triggered fresh cell mass $(6.8 \pm 0.4 \mathrm{FW})$ which was different from the cells cultured in medium fortified with $45 \mathrm{~g} / \mathrm{L}$ sucrose i.e., optimal dried cell weight was noticed from the cells cultured in the medium fortified with $45 \mathrm{~g} / \mathrm{L}$ sucrose as compared to medium fortified with $15 \mathrm{~g} / \mathrm{L}$ (Table 4). Meanwhile, when the level of sucrose was further enhanced ( $60 \mathrm{~g} / \mathrm{L}$ or more), there was a reverse trend in cell growth was noticed.

The cells cultured in medium fortified with $15 \mathrm{~g} / \mathrm{L}$ sucrose yielded the lowest quercetin content $(4.4 \pm 0.3)$. However, the cells cultured in medium fortified with high sucrose dose (90 g/L) yielded $2.5 \pm 0.04$ 
Aswathy et al.: Isolation, Purification of Quercetin from in vitro Cell Suspension Culture

Table 4: Effect of different concentrations of sucrose on cell biomass and quercetin content $(\mathrm{mg} / \mathrm{g})$ of $\mathrm{C}$. pulcherima

\begin{tabular}{ccc}
\hline Sucrose content $(\mathrm{g} / \mathrm{L})$ & Cell biomass $(\mathrm{g} \mathrm{FW})$ & $\begin{array}{c}\text { Quercetin content } \\
(\mathrm{mg} / \mathrm{g})\end{array}$ \\
\hline 0 & $1.2 \pm 0.09$ & $0.33 \pm 0.02$ \\
15 & $6.8 \pm 0.4$ & $4.4 \pm 0.3$ \\
30 & $8.9 \pm 0.6$ & $11.1 \pm 0.6$ \\
45 & $10.4 \pm 0.8$ & $16.5 \pm 0.8$ \\
60 & $5.2 \pm 0.3$ & $5.8 \pm 0.36$ \\
75 & $4.2 \pm 0.38$ & $3.9 \pm 0.24$ \\
90 & $3.2 \pm 0.2$ & $2.5 \pm 0.04$ \\
\hline
\end{tabular}

$\mathrm{mg} / \mathrm{g}$ quercetin content. Meanwhile, its cell biomass yield was marginal $(3.2 \pm 0.02 \mathrm{~g} \mathrm{FW})$ and this resulted in to reduced quercetin. The amount of quercetin produced in the cells cultured in medium fortified with 45 to $75 \mathrm{~g} / \mathrm{L}$ sucrose achieved remarkable level i.e., $16.5 \pm 0.8-3.9 \pm 0.24 \mathrm{mg} / \mathrm{g}$, each of which was soundly different from the other experimental cell cultures sets. Among these three treatment, culture fortified with $45 \mathrm{~g} / \mathrm{L}$ sucrose showed the highest growth $(10.4 \pm 0.8 \mathrm{~g} \mathrm{FW})$ with optimal quercetin content, hence the addition of $45 \mathrm{~g} / \mathrm{L}$ sucrose into the cell culture of C. pulcherrima could be used for increasing quercetin level (Table 4).

The relation between quercetin content and sucrose concentration may be due to the osmolytic property of sugar i.e., the increased sucrose content leads to exosmosis in the cell cultures and the supply of $15 \mathrm{~g} / \mathrm{L}$ sucrose was found to be enough for cellular growth and carbon energy source for metabolism. However, enhanced sucrose level $(60 \mathrm{~g} / \mathrm{L}$ or higher) showed a reverse trend in cell growth of $C$. pulcherrima (ends in to plasmolysis). Similar trend was reported by Ramirez-Estrada et al. ${ }^{21}$ by fortifying the culture medium of cell suspension culture with increased sugar content resulted in reduced cell growth. This may be due to the increased osmotic potential in the cell or the high viscosity of the medium which in turn inhibit the normal nutrient uptake. However, Wang et al..$^{22}$ stated that if a medium contain all the nutrients in excess, an increase in sugar concentration could result in a proportional increase in cell biomass. Experimenting on Hypericum perforatum cell cultures, they reported that growth rate increased with increase in sucrose level in the medium (15, 30, 45 and $60 \mathrm{~g} / \mathrm{L})$ for cultures with initial inocula of 15 and $50 \mathrm{~g} /$ wet cells/L. The present results substantiate that higher sucrose level fortified into the culture medium reduce cell biomass due to the increase of osmotic potential which subsequently reduce the nutrient uptake.

The cells culture fortified with $15 \mathrm{~g} / \mathrm{L}$ sucrose exhibited the lowest quercetin content. However, the culture fortified with $90 \mathrm{~g} / \mathrm{L}$ sucrose yielded decreased cellular biomass and there by the synthesis of quercetin. It is plausible that the high level of sucrose could be related to osmotic stress which results in to cell death as supported by Zhao et al. ${ }^{23}$ and hence lower quercetin synthesis in C. pulcherrima cell cultures.

Meanwhile, the cell culture medium fortified with 45, 60 and $75 \mathrm{~g} / \mathrm{L}$ sucrose showed high quercetin synthesis. Therefore, sucrose level in the culture medium should not be exceeded $75 \mathrm{~g} / \mathrm{L}$ for optimal results. Wang et al. ${ }^{22}$ found that for cell suspension culture of Hypericum perforatum, the medium that produced higher cell densities had higher sucrose levels as compared to the medium that produced higher anthocyanin accumulation. This observation was the reverse for cell suspension culture of C. pulcherrima, whereby the medium that enhanced quercetin synthesis had higher sucrose levels and biomass production. A relatively increased concentration of sucrose was also reported to be favorable for flavonoid production in Fagopyrum tataricum cell culture ${ }^{23}$ the ajmalicine, serpentine, and quercetin in Citrullus colocynthis cell cultures ${ }^{24}$ the phenol production of Calligonum polygonoides ${ }^{25}$ the flavonoid accumulation in suspension cultures of Andrographis Paniculata ${ }^{26}$ as well as anthocyanin production of grape cells ${ }^{27}$ and Camptotheca acuminate cells. ${ }^{28}$ Phytochemical synthesis could be induced to a certain level of osmotic stress caused by higher sucrose concentration. ${ }^{23}$ The positive effects of osmotic potential $(-0.5$ to $0.9 \mathrm{MPa}$ ), triggered by increased sucrose concentrations in medium with anthocyanins accumulation was correlated in grapes cell cultures. ${ }^{29}$

\section{Elicitation}

After standardization of the cell suspension cultures to produce quercetin in optimized MS medium, application of elicitor and precursor were carried to enhance quercetin synthesis. UV-B rays ( 45 min treatment) increased marginally the yield of quercetin. C. pulcherrima in cell suspension cultures $(3.4 \pm 0.24 \mathrm{mg} / \mathrm{g} \mathrm{DW})$ on $18^{\text {th }}$ day which showed a significant accumulation on $24^{\text {th }}$ day under physical elicitation by UV light. Meanwhile, light $(24 \mathrm{~h})$ or dark $(24 \mathrm{~h})$ treatments result no significant changes in the quercetin level in the culture medium.

Similarly, no sound quercetin synthesis was noticed with organic elicitors like peptone water and yeast extract. Meanwhile, among organic elicitors, MS media fortified with coconut water $(10-50 \%)$ showed increased quercetin biosynthesis in C. pulcherrima $(5.2 \pm 0.36 \mathrm{mg} / \mathrm{g} \mathrm{DW})$ cultures. The addition of phenylalanine as precursor at lower dose enhanced quercetin content of cells in the plants, which ranged from $3.7 \pm 0.48-10.6$ $\pm 0.86 \mathrm{mg} / \mathrm{g}$ DW. Chemical elicitors, which include GA, ABA and SA at different concentrations, were successful in inducing quercetin biosynthesis in cell suspension cultures of $C$. pulcherrima (6.2 $\pm 0.5-14.6 \pm 1.0$ $\mathrm{mg} / \mathrm{g} \mathrm{DW}$ ). Impact of heavy metals was also analyzed, zinc sulphate and copper sulphate at various doses showed slight rise in quercetin accumulation $(2.4 \pm 0.3-6 \pm 0.4 \mathrm{mg} / \mathrm{g} \mathrm{DW})$, but the content was lower than that of SA or ABA treatments. MeJ did not showed remarkable increase in quercetin production in cell cultures.

Regardless of the parameters, the most promising effect on quercetin synthesis in cell suspension cultures was shown by chemical elicitors, SA $(50 \mu \mathrm{M})$ or ABA $(0.1 \mathrm{mg} / \mathrm{L})(14.6 \pm 1.0 \mathrm{mg} / \mathrm{g} \mathrm{DW}$ and $12.8 \pm 0.9 \mathrm{mg} / \mathrm{g} \mathrm{DW}$, respectively) (Table 5 ).

The present results were in consistent with Wang et al. ${ }^{21}$ who reported a positive correlation between MeJA and flavonoid synthesis in Hypericum perforatum. Similarly, Thanh et al..$^{30}$ showed that addition of $200 \mu \mathrm{M}$ MeJA considerably increased the ginsenoside content in Panax ginseng while, with the increasing concentration (above $200 \mu \mathrm{M}$ ) reduced the ginsenosides content. Bharati and Bansal ${ }^{31}$ reviewed that the increased flavonoid caused by MeJA in cell cultures was not always due to increased biomass growth but also by the induction of the enzymes to its synthesis. But in C. pulcherrima cell culture, since the addition of MeJA did not increase the cell biomass and quercetin synthesis. As reported by El-Nabarawy et al. ${ }^{32}$ Jasmonic acid and its derivatives play a role in the signal cascade pathway of enzymes catalyzing secondary metabolite synthetic pathways.

\section{Effect of sucrose concentration and day of elicitation by GA/ABA}

The results clearly showed that culture medium fortified with $45 \mathrm{~g} / \mathrm{L}$ sucrose and $0.1 \mathrm{mg} / \mathrm{L}$ of $\mathrm{ABA}$ or $50 \mu \mathrm{M}$ GA was not significantly different from the cultures grown in their absence. Cell biomass was also not influenced by the addition of these elicitors at different days into the culture media with $45 \mathrm{~g} / \mathrm{L}$ sucrose. However, the amount of cell biomass produced was significantly lower than using the culture medium containing $30 \mathrm{~g} / \mathrm{L}$ sucrose. Cell proliferation medium containing $30 \mathrm{~g} / \mathrm{L}$ or $45 \mathrm{~g} / \mathrm{L}$ sucrose with or without the addition of these elicitors did not affect quercetin biosynthesis. However, cells cultured in the medium fortified with $45 \mathrm{~g} / \mathrm{L}$ sucrose without these showed the maximum quercetin content (Table 4). The reason may be the different feeding time did not influence the synthesis of quercetin. Zhang et al. ${ }^{33}$ reported a controversial opinion i.e., addition of jasmonic acid at different feeding time regulates the anthocyanin accumulation in cell suspension cultures of Vitis vinifera. Sajjalaguddam and Paladugu ${ }^{34}$ noticed application of phenylalanine enhances quercetin content in in vitro cultures of Abutilon 


\begin{tabular}{|c|c|c|c|}
\hline Elicitors combinations & $\begin{array}{l}\text { Quercetin } \\
\text { synthesis } \\
(\mathrm{mg} / \mathrm{g})\end{array}$ & $\begin{array}{c}\text { Elicitors } \\
\text { combinations }\end{array}$ & $\begin{array}{l}\text { Quercetin synthesis } \\
\qquad(\mathrm{mg} / \mathrm{g})\end{array}$ \\
\hline UV & $3.4 \pm 0.24$ & 25 & $5 \pm 0.3$ \\
\hline Light (24h) & $2.2 \pm 0.2$ & 50 & $6.3 \pm 0.4$ \\
\hline Dark (24h) & $1 \pm 0.07$ & 75 & $6.0 \pm 0.4$ \\
\hline Yeast extract (\%) & & 100 & $5.7 \pm 0.34$ \\
\hline 0.1 & $1.7 \pm 0.06$ & $\mathrm{GA}(\mathrm{mg} / \mathrm{L})$ & \\
\hline 0.2 & $1.8 \pm 0.07$ & 0.05 & $5.2 \pm 0.36$ \\
\hline 0.3 & $1.8 \pm 0.07$ & 0.1 & $5.9 \pm 0.4$ \\
\hline 0.4 & $1.7 \pm 0.06$ & 0.5 & $6.2 \pm 0.5$ \\
\hline 0.5 & $1.5 \pm 0.05$ & 1 & $7.4 \pm 0.58$ \\
\hline Peptone (\%) & & 1.25 & $10.6 \pm 0.7$ \\
\hline 0.001 & $1.9 \pm 0.10$ & 1.5 & $10.4 \pm 0.69$ \\
\hline 0.025 & $2.2 \pm 0.14$ & $\mathrm{ABA}(\mathrm{mg} / \mathrm{L})$ & \\
\hline 0.05 & $2.4 \pm 0.17$ & 0.05 & $10.2 \pm 0.69$ \\
\hline 0.075 & $2.0 \pm 0.25$ & 0.1 & $12.8 \pm 0.9$ \\
\hline 0.1 & $1.7 \pm 0.24$ & 0.5 & $10 \pm 0.8$ \\
\hline Coconut water (\%) & & 1 & $10 \pm 0.8$ \\
\hline 10 & $1.6 \pm 0.2$ & 1.25 & $8.7 \pm 0.76$ \\
\hline 20 & $2.0 \pm 0.3$ & 1.5 & $7.4 \pm 0.66$ \\
\hline 30 & $2.6 \pm 0.35$ & $\mathrm{SA}(\mu \mathrm{M})$ & \\
\hline 40 & $5.2 \pm 0.5$ & 1 & $10 \pm 0.8$ \\
\hline 50 & $4.3 \pm 0.4$ & 10 & $11.7 \pm 0.9$ \\
\hline $\mathrm{CuSO} 4(\mu \mathrm{M})$ & & 25 & $12 \pm 0.94$ \\
\hline 25 & $2.4 \pm 0.3$ & 50 & $14.6 \pm 1.0$ \\
\hline 50 & $4.1 \pm 0.46$ & 75 & $12.1 \pm 0.94$ \\
\hline 75 & $5.3 \pm 0.56$ & 100 & $9 \pm 0.78$ \\
\hline 100 & $5.8 \pm 0.58$ & MeJA $(\mu \mathrm{M})$ & \\
\hline Phenyl alanine $(\mu \mathrm{M})$ & & 100 & $3.3 \pm 0.15$ \\
\hline 100 & $3.7 \pm 0.48$ & 200 & $4.0 \pm 0.18$ \\
\hline 200 & $4.4 \pm 0.5$ & 300 & $5.1 \pm 0.2$ \\
\hline 300 & $6.2 \pm 0.6$ & 500 & $3.7 \pm 0.1$ \\
\hline 400 & $10.6 \pm 0.86$ & 750 & $3.1 \pm 0.08$ \\
\hline 500 & $9.7 \pm 0.78$ & 1000 & $2.8 \pm 0.04$ \\
\hline $\mathrm{ZnSO} 4(\mu \mathrm{M})$ & & & \\
\hline
\end{tabular}

indicum. Masoumian et al. ${ }^{35}$ evaluated the effect of precursors on flavonoid production in Hydrocotyle bonariensis callus tissues. Jedinak et al. ${ }^{36}$ compared flavonoid production in plant tissue cultures using biotic and abiotic factors. Shinde et al..$^{37}$ optimized production of isoflavones in cell cultures of Psoralea corylifolia using elicitation and precursor feeding.

The ${ }^{13} \mathrm{C}$-NMR spectrum showed carbonyl group at $176.2 \mathrm{ppm}$ and aromatic carbon group from 93.8-164.3 ppm (Figure 3.). The corresponding ${ }^{13} \mathrm{C}$ NMR peak positions for isolated compound were showed resemblance with the pure quercetin which was also confirmed by previous literatures. 93.8, 98.6, 103.4, 115.4,116.0 (Ar-C) , 120.4, 122.4, 136.1, (Ar-C) , 145.5, (Ar-C) , 147.2, (Ar-C), 148.1, (Ar-C) , 156.6, (Ar-C), 161.1, $(A r-C), 164.3,(A r-C)$ and 176.2, $(A r-C=O)$. Thus, it can be confirmed that the isolated compound is found to be quercetin. Structural characterization of purified compounds using NMR analysis showed the presence of nine compounds which includes, quercetin, isoquercetin, quercetrin, rutin, quercetin 3-O- $\beta$-D-xyloside (Reinutrin), quercetin 3-Oarabinopyranoside (Guajaverin), quercetin 3-O- $\alpha$-arabinopyranosyl $(1 \rightarrow 2) \beta$-galactopyranoside, and Isorhamnetin 3-O-rutinoside (Narcissoside) (Figure 3). ${ }^{38,39,40}$ Besides the expected products one unknown quercetin glycosides from in vitro cultures were noticed by NMR analysis in the plants, of which the biological significance remains to be explored.

\section{CONCLUSION}

Quercetin is a naturally occurring flavone found in many medicinal species in the form of quercetin glucosides. Quercetin possesses multiple therapeutic values. In vitro culture offer valuable tool in enhancing the synthesis of secondary metabolites. The present investigation reveals an 
optimal protocol for the synthesis of quercetin in C. pulcherima. Quercetin content recorded in cell suspension culture was significantly higher compared with in vivo plants grown in fields. Further, the compound was identified by NMR analysis. Future studies are warranted to fractionate the lead molecule, its purification and evaluation of its biological potentialities.

\section{ACKNOWLEDGEMENT}

The authors gratefully acknowledge Kerala State Council for Science, Technology and Environment, Govt. of Kerala for providing financial assistance through the major project related with his work.

\section{CONFLICT OF INTEREST}

The authors declare that there are no conflicts of interest pertaining to this work.

\section{ABBREVIATION USED}

HPLC- DAD: High-Performance Liquid Chromatography with DiodeArray Detection; NMR: Nuclear Magnetic Resonance; 2,4-D-2,4: Dichlorophenoxyacetic acid; BA: Benzyl Amino Purine; Kin: Kinetin; NAA: Naphtalic Acetic Acid; TDZ: Thidiazuron; IBA: Indole3-butyric acid; DW: Dry weight; FW: Fresh weight; MeJA: Methyl jasmonate; ABA: Abscisic acid; SA: Salicylic acid; $\mathbf{H g C l}_{2}$ : Mercuric chloride; $\mathbf{C u S O}_{4}$ : Copper sulphate; $\mathbf{Z n S O}_{4}$ : Zinc sulphate.

\section{REFERENCES}

1. Kumar S, Pandey AK. Chemistry and Biological Activities of Flavonoids: An Overview. The Scientific World J. 2013; 162750:1-16.

2. Sharma V, Rajani GP. Evaluation of Caesalpinia pulcherrima Linn. for anti-inflammatory and antiulcer activities. Indian J Pharmacol. 2011;43(2):168-71.

3. Patwardhan BD, Warude P, Pushpangadan N Bhatt. Ayurveda and traditional Chinese medicine: A comparative overview. ECAM. 2005;2(4):465-73.

4. Rout GR, Samantaray S, Das P. In vitro manipulation and propagation of medicinal plants. Biotechnol Adv. 2000;18(2):91-120.

5. Oksman-Caldentey KM, Inzé D. Plant cell factories in the postgenomic era: new ways to produce designer secondary metabolites. Trends Plant Sci. 2004;9(9):433-40.

6. Murashige T, Skoog F. Revised medium for rapid growth and bioassays with tobacco tissue cultures. Physiol Plant. 1962;15:473-97.

7. Chan LK, See KS, Hoon LP, Lim. Effect of plant growth regulators and subculture frequency on callus culture and the establishment of Melastoma malabathricum cell suspension culture for the production of pigments. Biotechnol. 2008 7(4):678-85

8. Srinath Rao, Usha K, Arjun. Production of secondary metabolites from callus cultures of Centella asiatica (L.) Urban Annals of Phytomedicine. 2015:4(1):74-8,

9. Sheeba E, Palanivel S, Parvathi S. Effect of plant growth regulators on callus induction in Physalis minima Linn. IJIRSET. 2010;2(9):4847-51.

10. Ashtari R, Omidi M, Heidari, Abdoli M, Mahdinejad, Zare AR. Establishment of an efficient callus induction and plant regeneration system in Ducrosia anethifolia (Dc.) an important medicinal plant . TJS. 2014;2(2):132-41.

11. Tang YP, Liu XQ, Wahiti Gitur RU, Chen LQ. Callus Induction and Plant Regeneration from in vitro Cultured Leaves, Petioles and Scales of Lilium Leucanthum (Baker) Baker Biotechnol. \& Biotechnol. 2010; 24(4):2071-7.

12. Amali, Kingsley, Ignacimuthu SJ. High frequency callus induction and plant regeneration from shoot tip explants of Sorghum bicolor L. Moench. Int J Pharm Pharm Sci. 2014;6(6):213-6.

13. Lood SZ, Hasbullah NA, Mazlan MAA, Lassim MM. Micropropagation and Callus Induction In Lagenaria siceraria L. International Conference on Latest Trends in Food, Biological \& Ecological Sciences (ICLTFBE'14). 2014;15-6.

14. Bonyanpour A, Khosh-Khui M. Callus Induction and Plant Regeneration in Punica granatum L. 'Nana' from Leaf Explants. JCEA. 2013:14(3):75-83.

15. Hasan MF, Das R, Rahman MS, Rashid MH, Hossain MS, Rahman M. Callus induction and plant regeneration from shoot tips of chakunda (Cassia obtusifolia L.) Int J Sustain Crop Prod. 2008;3(6):6-10
16. Hasan MF, Rahman MS, Hossain MS, Rahman M. Studies on in vitro callus induction and regeneration from nodal explants of Cassia alata L. Progress Agri. 2008;19(1):39-44

17. Tan SH, Musa R, Ariff A, Maziah M. Effect of Plant Growth Regulators on Callus Cell Suspension and Cell Line Selection for Flavonoid Production from Pegaga (centella asiatica L. urban) American J Biochem Biotech. 2010;6(4):284-99.

18. Aghaei P, Bahramnejad AA, Mozafari. Effect of different plant growth regulators on callus induction of stem explants in Pistacia atlantica subsp. Kurdica. PKJ. 2013;2(3):108-12.

19. Song-Chol Mun, Gwan-Sim Mun. Development of an efficient callus proliferation system for Rheum coreanum Nakai, a rare medicinal plant growing in Democratic People's Republic of Korea. Saudi J Biol Sci. 2016;23(4):488-94.

20. Abrie AL, Van staden J. Micropropagation of the endangered Aloe polyphylla. Plant Growth Regu. 2001;33(1):19-23.

21. Ramirez-Estrada K, Vidal-Limon H, Hidalgo D, Moyano E, Golenioswki M, Cusidó RM , et al. Elicitation, an Effective Strategy for the Biotechnological Production of Bioactive High-Added Value Compounds in Plant Cell Factories. Mole. 2016;21(182):1-24.

22. Wang J, Qian J , Yao L, Lu Y. Enhanced production of flavonoids by methyl jasmonate elicitation in cell suspension culture of Hypericum perforatum. Biores Bioprocess. 2015:2(1):1-8.

23. Zhao J, Zou L, Zhang C, Li Y, Peng L, Xiang D, et al. Efficient production of flavonoids in Fagopyrum tataricum hairy root cultures with yeast polysaccharide elicitation and medium renewal process. Phcog Mag. 2014;10(39):234-40.

24. Meena M, Meena R, Patni V. Effect of elicitor on quercetin production in cell cultures of Citrullus colocynthis (Linn.) Schrad. Pharm innov. 2014;3(2):18-23

25. Owis Al, Abdelwahab NS, Abul-Soad AA. Elicitation of phenolics from the micropropagated endangered medicinal plant Calligonum polygonoides $\mathrm{L}$. (Polygonoaceae). Phcog Mag. 2016;12(4):465-70.

26. MendhulkarVD, Vakil MMA. Chitosan And Aspergillus Niger Mediated Elicitation Of Total Flavonoids In Suspension Culture Of Andrographis Paniculata (Burm.F.) Nees. Int J Pharm Bio Sci. 2013;4(4): 731-40.

27. Do CB, Cormier F. Effects of low nitrate and high sugar concentrations on anthocyanin content and composition of grape (Vitis vinifera L.) cell suspension. Plant Cell Rep. 1991;9(9):500-4

28. Pasqua G, Monacelli B, Mulinacci N, Rinaldi S, Giaccherini C, Innocenti M et al. The effect of growth regulators and sucrose on anthocyanin production in Camptotheca acuminate cell cultures. Plant Physiol Biochem. 2005;43(3):293-8.

29. Do CB, Cormier F. Accumulation of anthocyanin enhanced by a high osmotic potential in grape (Vitis vinifera L.) cell suspension. Plant Cell Rep. 1990;9(3):143-6

30. Thanh NT, Murthy HN, Yu KW, Hahn EJ , Paek KY. Methyl jasmonate elicitation enhanced synthesis of ginsenoside by cell suspension cultures of Panax ginseng in 5-I balloon type bubble bioreactors. Appl Microbiol Biotechnol. 2005;67(2):197-201.

31. Bharati AJ, Bansal YK. In vitro production of flavonoids: a review. WJPPS. 2014;3:508-33.

32. El-Nabarawy MA, El-Kafafi SH, Hamza MA Omar MA. The effect of some factors on stimulating the growth and production of active substances in Zingiber officinale callus cultures. Ann Agric Sci. 2015;60(1):1-9

33. Zhang W, Curtin C, Kikuchi M, Franco C. Integration of jasmonic acid and light irradiation for enhancement of anthocyanin biosynthesis in Vitis vinifera suspension cultures. Plant Sci. 2002;162(3):459-68.

34. Sajjalaguddam R, Paladugu A. Phenylalanine enhances Quercetin content in In vitro cultures of Abutilon indicum L. JAPS. 2015;5(10):80-4.

35. Masoumian M, Arbakariya A, Syahida A, Maziah M. Effect of precursors on flavonoid production by Hydrocotyle bonariensis callus tissues. Afr J Biotechnol. $2011 ; 10(32): 6021-9$

36. Jedinak A, Farago J, Psenakova I, Maliar T. Approaches to flavonoid production in plant tissue cultures. Biologia Bratisl. 2004;59(6):697-10.

37. Shinde AN, Malpathak N, Fulzele DP. Optimized production of isoflavones in cell cultures of Psoralea corylifolia L. using elicitation and precursor feeding. Biotechnol Bioprocess Eng. 2009;14(5):612-8.

38. Fossen T, Andersen OM. Spectroscopic Techniques Applied To Flavonoids. In Flavonoids: Chemistry, Biochemistry and Applications. Edited by Andersen OM, Markham KR. Boca Raton: Taylor \& Francis Group. 2006;37-142.

39. Piccinelli AL, Veneziano A, Passi S, Simone F, Rastrelli L. Flavonoids glycosides from whole cottonseed by product. Food Chem. 2007;100(1):344-9.

40. Rodrigues ED, Silva DB, Oliveira DCR, Silva GVJ. DSY NMR applied to analysis of flavonoid glycosides from Bidens sulphurea. Magn Reson Chem. 2009; 47(12):1095-100. 


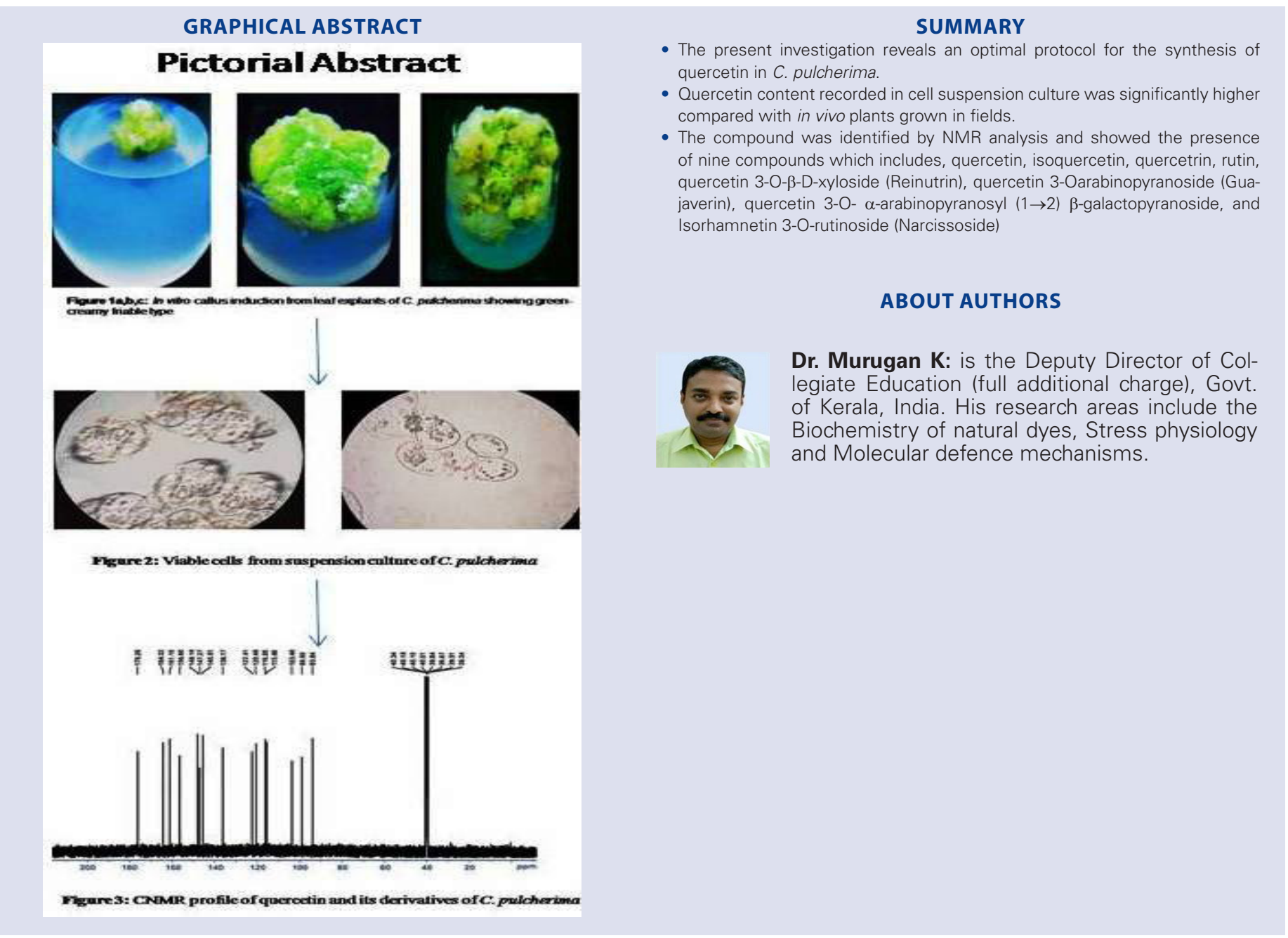

Cite this article: Aswathy JM, Murukan G, Lawarence B, Murugan K. Isolation, Purification of Quercetin from in vitro Cell Suspension Culture of Caesalpinia pulcherrima and its Analysis by HPLC -DAD and NMR. Pharmacog J. 2017;9(6)Suppl:s44-s51. 